\title{
Penggunaan daun ketumbar (coriandrum sativum L.) sebagai penjernih air di Desa Meka Praya Tengah
}

\author{
Pahrurrozi $^{1^{*}}$, Dwi Agustini ${ }^{2}$, Rio Satriyantara ${ }^{3}$ \\ 1,2,3 Prodi Biologi, FMIPA, Universitas Nahdlatul Wathan Mataram \\ occionfire@gmail.com
}

\begin{abstract}
Water is the principal human needs. Utilization in all life aspect. However water availability in every area is different. Meka Village with location in Central Praya Distric Central Lombok usually deficiency of clean water in dry season. Public make use of surface water to fulfill needs. This community dedication aim at give society way to process and use coriander leaves as ingredient water clarifier. Coriander leaves have absorbs ability to solute in the water and have antioxsidants coumpound. This proven that application coriander leaves able to lowered water temperature amounting to $3,4{ }^{\circ} \mathrm{C}$ and ph amounting to 5,4. Based on these research could concluded that coriander leaves able to clarifier water because have nature to absorbs solute in the water and also contain antioxidants compound
\end{abstract}

Keywords: coriander leaves, water clarifier, antioxidants

\begin{abstract}
Abstrak
Air merupakan kebutuhan manusia yang paling mendasar. Pemanfaatannya dalam segala aspek kehidupan. Namun ketersediaan air disetiap daerah berbeda-beda. Desa Meka yang berada di Kecamatan Praya Tengah Lombok Tengah selalu kekurangan air bersih di musim kemarau. Masyarakat memanfaatkan air permukaan untuk memenuhi kebutuhan. Kegiatan pengabdian ini bertujuan untuk memberikan pelatihan kepada masyarakat mengenai cara penggunaan daun ketumbar sebagai bahan penjernih air. Daun ketumbar memiliki sifat absorbs terhadap zat terlarut dalam air dan memiliki senyawa antioksidan. Terbukti aplikasi daun ketumbar mampu menurunkan suhu rata-rata air sebesar $3,4{ }^{\circ} \mathrm{C}$ dan ph air sebesar 5,4. Berdasarkan temuan tersebut dapat disimpulkan bahwa daun ketumbar mampu menjernihkan air karena memiliki sifat absorbs dan memiliki kandungan senyawa antioksidan.
\end{abstract}

Kata Kunci: daun ketumbar, penjernih air, antioksidan

\section{PENDAHULUAN}

Air merupakan kebutuhan utama semua mahluk hidup. Secara biologis air dimanfaatkan untuk pengisi cairan sel dan sangat berpera dalam metabolisme mahluk hidup. Air juga dibuuhkan dalam proses pembentukan darah, hormon, dan enzim, serta berperan sebagai media transportasi dan detoksifikasi. Dalam kehidupan manusia sehari-hari peran air juga sangat penting. Selain dikonsumsi air juga digunakan untuk berbagai keperluan seperti memasak, mandi, mencuci dan lain sebagainya (Wulan, 2005).

Kenyataannya di beberapa daerah Kebutuhan akan air bersih berbanding terbalik dengan Ketersediaan air itu sendiri. Beberapa daerah harus diberi pasokan air bersih 
dari daerah lain. Hal ini terjadi karena perbedaan karakteristik iklim masing-masing daerah. Iklim berpengaruh dalam siklus hidrogen yang memberi pasokan air dari hujan. Karateristik topograpi tanah juga sangat berpengaruh, dimana kemampuan tanah dalam mengikat air berbeda-beda. Keadaan tersebut mengakibatkan ketersediaan air tanah setiap daerah juga berbeda (Newman, 2008).

Desa Meka merupakan salah satu desa yang berada di Kecamatan Praya Tengah. Setiap musim kemarau desa ini mengalami kekurangan ketersediaan air tanah. Warga desa yang membutuhkan air terpaksa menggunakan air permukaan untuk kebutuhan sehari-hari. Air permukaan diperoleh dari anak sungai, kolam dan waduk-waduk kecil. Secara umum kondisi air permukaan yang digunakan kurang higienis dan tidak jernih, sehingga dari segi kesehatan penggunaan air ini dapat menimbulkan berbagai penyakit seperti kolera, diare, dan keracunan berbagai jenis logam berat yang terlarut dalam air seperti timbal dan mercuri (Sasongko, 2014).

Berdasarkan masalah tersebut maka dibutuhkan suatu bahan untuk menjernihkan dan meningkatkan kualitas air. Sebelumnya masyarakat telah menggunakan berbagai cara dalam menjernihkan air. Salah satunya adalah dengan menggunakan kerikil dan ijuk. Cara tersebut memang mampu menjernihkan air namun memerlukan waktu yang relatif lama dan tidak paraktis dalam aplikasinya.

Berdasarkan literatur daun ketumbar (Coriandrum sativum L.) memiliki kemampuan untuk menjernihkan air, dan menyerap logam-logam berat yang terlarut. Daun ketumbar yang digunakan adalah daun yang telah dikeringkan dan diletakkan dalam wadah penampungan air. Kelebihan daun ketumbar sebagai bahan penjernih air adalah sifat absorbs yang mampu menyerap logam berat dan zat terlarut lain dalam air, mudah proses pembuatannya dan praktis dalam aplikasinya.

\section{METODE PELAKSANAAN}

Kegiatan pengabdian ini dalaksanakan pada bulan Agustus tahun 2020. Tahapan kegiatan pengabdian ini dilakukan secara bersama-sama oleh tim Dosen Biologi UNW Mataram. Sasaran kegaiatan ini adalah masyarakat Desa Meka Kecamatan Praya Tengah Lombok Tengah Provinsi Nusa Tenggara Barat. Pendekatan yang digunakan kepada masyarakat adalah dengan memberikan penjelasan dan pengarahan mengenai pemanfaatan daun ketumbar sebagai bioabsorbsi. dan mempraktikan cara pembuatan bahan penjernih air dari daun ketumbar. Adapun langkah-langkah kegiatan pengabdian selengkapnya adalah sebagai berikut:

\subsection{Pembutan simplisia daun ketubar.}

Daun ketumbar dipetik yang sudah dewasa, kemudian dicuci, ditiriskan kemudian diangin-anginkan di tempa terbuka. Proses pembutan simplisia membutuhkan waktu kurang lebih satu minggu. Daun ketumbar yang siap pakai adalah daun ketumbar yang sudah benar-benar kering. 
2.2 Pembuatan wadah simplisia.

Simplisia yang telah siap digunakan harus ditempatkan dalam wadah khusus. Wadah yang digunakan berupa kain muslin. Simplisia daun ketumbar dimasukkan ke dalam kain muslin kemudian dijahit atau diikat. Bahan alami penjernih air siap digunakan.

Pengaplikasian bahan penjernih air ini cukup mudah. Hanya menepatkan simplisia tersebut dalam wadah yang telah diisi air, maka bahan penjernih air tersebut akan bekerja untuk menyerap logam berat dan zat-zat terlarut lain dalam air. Penggunaaan simplisia daun ketumbar maksimal dalam dua kali penggunaan. Seterusnya harus diganti dengan simplisia yang baru.

Guna lebih memperoleh data yang lebih akurat mengenai kinerja daun ketumbar dalam menjernihkan air. Kami mencoba untuk mengukur kualitas air yang telah diendapkan dengan daun ketumbar. Parameter yang diukur berupa parameter fisik air berupa suhu dan ph. Hasil pengukuran kualitas air tersebut dapat diketahuia dalam bab berikutnya

\section{HASIL DAN PEMBAHASAN}

Ketumbar (Coriandrum sativum L.) merupakan tanaman herba yang dikategorikan kedalam tanaman rempah-rempah. Umumnya digunakan sebagai bumbu penyedap masakan. Bagian yang paling sering digunakan adalah daun dan bijinya. Penambahan daun ketumbar pada masakan bertujuan untuk menambah aroma masakan. Ketumbar memiliki kandungan vitamin c, kalium, seng, tembaga dan selenium (Kurniawati, 2010).

Selain sebagai bumbu masakan tanaman ini juga dimanfaatkan sebagai antimicroba, antifungi, dan antioksidan. Tanaman ketumbar memiliki kandungan essential oil (Eo) yang berupa senyawa aliphatic aldehyde, seperti deconal, decanal, cyclic, dan hydrocarbons. Senyawa tersebutlah yang memiliki manfaat sebagai antimicroba dan antioksidan. Hal ini dibuktikan oleh penelitian Pellegrini (2018) pada sediaan in vitro baktei Salmonella spp. Aplikasi essential oil daun dan biji ketumbar mampu menghambat pertumbuhan bakteri tersebut.

Daun ketumbar juga memiliki sifat sebagai bioabsorbs. Cara kerja daun ketumbar sebagai bioapsorbs adalah dengan cara melakukan pertukaran ion. Penggunaan daun ketumbar sebagai bioapsorbs memiliki beberapa kelebihan diataranya biaya operasional yang rendah, bahan baku yang banyak tersedia, cara kerja yang efesien (Iqbal, 2018). Proses absorbs materi terlarut dari air, mengakibatkan perubahan pada sifat kimia air. Perubahan itu meliputi perubahan suhu dan ph air. Untuk mengetahui tingkat perubahan air tersebut kami melakukan pengukuran suhu dan ph yang dtampilkan pada Tabel 1. 
Tabel 1. Perubahan Sifat Kimia Air Sebelum Dan Setelah Aplikasi

\begin{tabular}{|c|c|c|c|c|c|c|}
\hline No & $\begin{array}{c}\text { Suhu } \\
\text { Sebelum } \\
\text { Aplikasi }\end{array}$ & $\begin{array}{c}\text { Suhu } \\
\text { Setelah } \\
\text { Aplikasi }\end{array}$ & $\begin{array}{c}\text { Ph } \\
\text { Sebelum } \\
\text { Aplikasi }\end{array}$ & $\begin{array}{c}\text { Ph } \\
\text { Setelah } \\
\text { Aplikasi }\end{array}$ & $\begin{array}{c}\text { Rata-rata } \\
\text { Perubahan } \\
\text { Suhu }\end{array}$ & $\begin{array}{c}\text { Rata-rata } \\
\text { Perubahan } \\
\mathrm{Ph}\end{array}$ \\
\hline 1 & $27^{\circ} \mathrm{C}$ & $25^{\circ} \mathrm{C}$ & 5 & 5,8 & $2{ }^{\circ} \mathrm{C}$ & 8 \\
\hline 2 & $28^{\circ} \mathrm{C}$ & $24^{\circ} \mathrm{C}$ & 5,2 & 5,6 & $4^{\circ} \mathrm{C}$ & 4 \\
\hline 3 & $27^{\circ} \mathrm{C}$ & $24^{\circ} \mathrm{C}$ & 5,2 & 5,6 & $3^{\circ} \mathrm{C}$ & 4 \\
\hline 4 & $28^{\circ} \mathrm{C}$ & $25^{\circ} \mathrm{C}$ & 5,2 & 5,6 & $3^{\circ} \mathrm{C}$ & 4 \\
\hline 5 & $29^{\circ} \mathrm{C}$ & $26{ }^{\circ} \mathrm{C}$ & 5 & 5,7 & $3{ }^{\circ} \mathrm{C}$ & 7 \\
\hline 6 & $29^{\circ} \mathrm{C}$ & $24^{\circ} \mathrm{C}$ & 5,4 & 6 & $5^{\circ} \mathrm{C}$ & 6 \\
\hline 7 & $27^{\circ} \mathrm{C}$ & $24^{\circ} \mathrm{C}$ & 5,4 & 5,8 & $3{ }^{\circ} \mathrm{C}$ & 4 \\
\hline 8 & $28^{\circ} \mathrm{C}$ & $24^{\circ} \mathrm{C}$ & 5,3 & 6 & $4^{\circ} \mathrm{C}$ & 3 \\
\hline 9 & $28^{\circ} \mathrm{C}$ & $25^{\circ} \mathrm{C}$ & 5 & 6 & $3{ }^{\circ} \mathrm{C}$ & 10 \\
\hline 10 & $29^{\circ} \mathrm{C}$ & $25^{\circ} \mathrm{C}$ & 5,4 & 5,7 & $4^{\circ} \mathrm{C}$ & 3 \\
\hline 11 & $29^{\circ} \mathrm{C}$ & $26{ }^{\circ} \mathrm{C}$ & 5,4 & 6 & $3{ }^{\circ} \mathrm{C}$ & 6 \\
\hline 12 & $28^{\circ} \mathrm{C}$ & $24^{\circ} \mathrm{C}$ & 5 & 6 & $4^{\circ} \mathrm{C}$ & 10 \\
\hline 13 & $28^{\circ} \mathrm{C}$ & $25^{\circ} \mathrm{C}$ & 5,3 & 5,6 & $3{ }^{\circ} \mathrm{C}$ & 3 \\
\hline 14 & $27^{\circ} \mathrm{C}$ & $24^{\circ} \mathrm{C}$ & 5,4 & 5,8 & $3{ }^{\circ} \mathrm{C}$ & 4 \\
\hline 15 & $29^{\circ} \mathrm{C}$ & $25^{\circ} \mathrm{C}$ & 5,5 & 5,9 & $4^{\circ} \mathrm{C}$ & 4 \\
\hline & & & & & $\mathrm{r}=3,4^{\circ} \mathrm{C}$ & 5,4 \\
\hline
\end{tabular}

Berdasaarkan Tabel 1 dapat diketahui bahwa terjadi penurunan suhu rata-rata air yang telah diberi aplikasi. Penurunan rata-rata sebesar $3,4{ }^{\circ} \mathrm{C}$. Sedangakan ph air yang telah diberi aplikasi mengalami kenaikan menuju angka normal. Jumlah kenaikan ph air rata-rata sebesar 5,4. Terjadinya perubahan sifat kimia air disebabkan air yang diolah merupakan air permukaan. Air permukaan berasal dari air hujan yang mengandung banyak partikel zat lain. Secara umum air permukaan memang tidak layak dikonsumsi karena memiliki suhu yang tinggi dan ph yang tidah normal.

\section{SIMPULAN}

Penggunaan daun ketumbar (Coriandrum sativum L.) sebagai bahan penjernih air terbukti efektif meningkatkan kualitas air, ini dibuktikan melalui terjadinya perubahan suhu dan ph air.

\section{UCAPAN TERIMA KASIH}

Pengabdian masyarakat ini tidak akan terlaksana tanpa bantuan dari berbagai pihak. Untuk itu penulis merasa perlu untuk mengucapkan terima kasih kepada rekan-rekan dosen, dan mahasiswa UNW Mataram yang telah bekerjasama dalam kegiatan ini. Kepada Bapak Kepala Desa Meka yang telah memberikan izin kegiatan ini, dan kepada seluruh masyarakat Desa Meka yang telah antusias menerima kehadiran kami. 


\section{REKOMENDASI}

Rekomendasi menggambarkan hal-hal yang akan dilakukan terkait dengan ide pengabdian selanjutnya. Hambatan atau masalah yang dapat mempengaruhi hasil pengabdian juga disajikan pada bagian ini.

Dengan meningkatnya kebutuhan akan air bersih maka kedepannya kami akan mencoba untuk membuat dan mengaplikasikan essential oil dari daun dan biji ketumbar sebagai bahan penjernih air. Secara aplikatif essential oil jauh lebih praktis karena kita tidak perlu membuat siplisia lagi. Sehingga kedepannya agen atau bahan penjernih air dapat berupa essential oil yang telah siap digunakan.

\section{REFERENSI}

Ausland, L.M, et. al. 2020. Growth Spectrum Complexity Dictates Aromatic Intensity in Coriander (Coriandrum sativum L.) frontiers in plant science : Vol, 11 Page: 462. www. frontiersin.org.

Dalimartha, S. 2008. Atlas Tumbuhan Obat Indonesia Jilid 5. Jakarta: Pustaka Bunda.

Hou.Y.2016. Biosorption of Cadmium and Manganese Using Free Cells of Klebsiella sp. Isolated From Waste Water. Plos One Journal. https://www.researchgate.net/publication/283303701

Iqbal. M. J. et. al. 2018. Coriander (Coriandrum sativum L.) Bioactive Molecules and Health Effect. National Institute of Food and Technology. Faisalabad: University of Agriculture.

Kurniawati, N. 2010. Sehat dan Cantik Alami Berkat Khasiat Bumbu Dapur. Bandung : PT Mizan Pustaka.

Newman,. M. C, \& Clements. W. H. 2008. Ecotoxicology A Comperhensive Treatment. Ney York: CRC Press.

Pallegrini,. M. et .al . 2020. Salmonella enterica Control in Stick Carrot Through in Corporation of Coriander Seeds Essential Oil in Sustainable Washing Treatments. Frontiers in Plant Science: Vol. 4. www. Frontiersin.org.

Sasongko,.E.B. et.al. 2014. Kajian Kualitas Air dan Penggunaan Sumur Gali Oleh Masyarakat di Sekitar Sungai Kaliyasa Kabupaten Cilacap. Jurnal Ilmu Lingkungan: Volume 12 Issue 2.

Sinaga, P.S. 2019. Uji Aktivitas Antijamur Ekstrak Daun Ketumbar (Coriandrum sativum L.) Terhadap Candida albicans, Microsporum cams, dan Trichophyton mentagrophytes. Medan: Program Studi Sarjana Farmasi. USU.

Sogara,. P.P.U.2014. Pengaruh Ekstrak Etanol Buah Ketumbar (Coriandrum sativum L.) Terhadap Penurunan Kadar Gula Darah Tikus Putih Yang Diinduksikan Aloksan. Parmacon: Jurnal Ilmiah Parmasi UNSRAT: Vol.3, No.3.

Sutandi,. M. C. 2014. Penelitian Air Bersih di PT. Summit

Plast Cikarang. Jurnal Teknik Sipil Volume 8 Nomor 2.

Torkos, S. 2008. The Canadian Encyclopedia of Natural Medicine. Canada: Jhon Wiley \& Sons Publihser.

Winarti,. S. et. al. 2018. Benefit of Coriander Leaves (Coriandrum sativum L.) to Reduce Heavy Metals Contamination in Road Shellfish. Jurnal of Physics.

Wulan,. A.I.S. 2005. Kualitas Air Bersih Untuk Pemenuhan Kebutuhan Rumah Tangga di Desa Pasarean Kecamatan Adiwerna Kabupaten Tegal. Semarang: Fakultas Ilmu Sosial UNNES.

Yildiz. H. 2016. Chemical Composition, Antimicrobial, and Antioxidant Activities of Essential Oil and Ethanol Extract of Coriandrum sativum L., Leaves From Turkey. International Journal of Food Properties. https:// www. Tandfomline.com/loi/ljfp20. 